\title{
DEMOGRAPHIC CHARACTERISTICS OF COVID-19 POSITIVE HEALTHCARE WORKERS AND COMPARISON WITH THE LITERATURE
}

\author{
Durmus Ensar, Guneysu Fatih
}

Emergency Department, Sakarya University Training and Research Hospital, Sakarya, Turkey

Primljen/Received 26. 01. 2021. god.

Abstract: Aim: It is aimed to examine the status and demographic characteristics of COVID-19 Reverse Transcription Polymerase Chain Reaction (RTPCR) positive staff working in the hospital during the pandemic period.

Material and methods: This is retrospective, descriptive research. All hospital personnel working at Sakarya Training and Research Hospital and tested positive for COVID-19 RT-PCR between 01/11/2020$30 / 11 / 2020$ were included in the study.

Results: During the study period, the number of hospital staff who tested positive for COVID-19 RTPCR was 340 people. Of the personnel, 228 (67.1\%) were female, the mean age of all healthcare workers was $32.7( \pm 8.3)$ years. The number of non-physician healthcare workers was $162(47.6 \%)$, workers were 143 (42.1\%), and physicians were 35 (10.3\%). Among all hospital personnel, the COVID-19 RT-PCR test was positive in emergency room workers, with a maximum of 61 people (17.9\%). It was followed by $43(12.6 \%)$ people working in non-COVID clean wards.

Conclusions: It would be beneficial for all staff working in the hospital during the pandemic to pay attention to apply personal protective equipment during their work, notwithstanding whether the COVID-19 patient is caring or not. Simultaneously, healthcare professionals should be careful about COVID-19 transmission in their social life outside of the hospital.

Key words: COVID-19, healthcare workers, emergency service.

\section{INTRODUCTION}

The COVID-19 pandemic appeared in China in 2019's last weeks, then spread to the world quickly; moreover, was eventually declared a pandemic by the World Health Organisation (WHO) on March 11, 2020 (1). During the pandemic period, with the increasing
Prihvaćen/Accepted 21. 02. 2021. god.

number of patients, healthcare facilities have suffered accelerated patient admission and workload. Thus, negative images were reflected by the press because of the inadequate personnel and deficiency of physical facilities. Healthcare workers were also affected both psychologically and physically during the pandemic process $(2,3)$. Working in personal protective equipment (PPE) for long periods has been problematic, however, in some hospitals, healthcare workers (HCW) have not been able to protect themselves adequately due to insufficient PPE (4). On September 2, the WHO Pan American Regional Office in Washington DC reported that 570,000 healthcare workers were infected with Covid-19, and 2500 of them died. (5). While some HCW who had COVID-19 disease survived the disease outpatient, some had to be hospitalised and treated. Unfortunately, some healthcare professionals passed away due to COVID-19they contracted during this period. WHO has reported that thousands of $\mathrm{HCW}$ worldwide died due to COVID-19 by September 17, 2020 (6). Publications state that these mortality rates are observed less in HCW who had a reasonable adaptation period and had adequate PPE compared to those who did not have this opportunity (7).

Due to the increasing workload, each healthcare worker's need has become more evident during the pandemic period. Therefore, it is also essential to ascertain healthcare professionals' status in the COVID-19 pandemic, in which units are riskier, to protect $\mathrm{HCW}$ and maintain health service delivery.

This study aimed to reveal the demographic characteristics of HCW who tested positive for COVID-19 at Sakarya University Training and Research Hospital (SEAH) between November 1, 2020, and November 30, 2020. The patients' age, gender, occupation and unitthey worked in, hospitalisation status, and mortality were examined, so the contribution to literature is to tell us which occupational group should be of greater 
concern, and in which areas; furthermore, to ascertain which healthcare professionals should be paid attention to more in the pandemic.

\section{MATERIAL AND METHODS}

This research is a retrospective, descriptive study. In this study, the demographic data of the HCW working at SEAH between November 1, 2020 to November 30, 2020 who were positive for the COVID-19 RT-PCR test were analysed. SEAH has a total of 4818 health workers. RT-PCR positive HCW who worked actively in all the hospital's campuses and units were included in the study. HCW who were not on active duty but found a positive COVID-19 RT-PCR test were excluded from the research.

\section{Definitions}

The wards in which RT-PCR tested positive or clinically suspected COVID-19 patients hospitalised were accepted as "COVID-19 Service" and intensive care units as "COVID-19 intensive care". Units that are not associated with the diagnosis, follow-up, or treatment of COVID-19 patients were called "clean". Warehouses and technical units that were not in direct contact with patients were grouped as "support areas". All laboratory areas such as pathology, microbiology, biochemistry, or emergency laboratory were grouped as "laboratories". Areas including, corridors, waiting rooms, public toilets, entrance foyer areas where patients could be found for a short time while passing through were classified as "General Areas".

While hospital personnel is grouped according to their staff, all specialist physicians, assistant physicians, and general practitioners were grouped as "doctors". Except for the doctor, employees such as nurses, physiotherapists, and orthopaedic technicians who contact patients were grouped as "non-physician healthcare workers". Cleaning personnel, security guards, technical service personnel, and secretaries, who did not have a diagnosis or treatment relationship with the patient, were sometimes needed in the patients' areas, were included in the "worker" group.

\section{Data collecting}

The data were obtained by scanning from the hospital automation system and patient files.

\section{Permissions}

Approval was obtained from the Ethics Committee of Sakarya University Faculty of Medicine (E71522473-050.01.04-6065 43).

\section{Statistical analysis}

IBM Statistical Product and Service Solutions (SPSS) V21.0 was used concerning statistical analysis. A Chi-square test was acquired for the association of categorical data. Results with $p<0.05$ were interpreted as statistically significant. The skewness and kurtosis scores were expected to be in the \pm 2 value range to specify whether the decentralised data match the regular distribution (8). Mann-Whitney U test was appropriated to compare independent data that did not submit to the normal distribution; moreover, results with $\mathrm{p}<0.05$ were acknowledged notable.

\section{RESULTS}

In SEAH, the number of COVID-19 positive $\mathrm{HCW}$ during the study period is 340 people. 112 $(32.9 \%)$ of this personnel were male, and 228 (67.1\%) were female. The average age of the personnel included in the study was $32.7( \pm 8.3)$, the median age value was 32 (min. 26 years, max. 56 years).

The number of hospitalised and treated patients among all COVID-19 positive HCW was 13 (3.8\%), 6 of them were men, and 7 were women. The average length of stay in hospital was 4.2 days (min. 2, max. 9 days). Of the 13 patients hospitalised, $2(0.6 \%)$ were treated in the intensive care unit and $11(3.2 \%)$ in the service. See Table 1 for inpatient data.

No deaths were observed among healthcare workers who tested positive for the PCR during the study period.

There was no statistically significant relationship between the gender of the patients and their hospitalisation status (Fisher's Exact Test, $\mathrm{p}=0.368$ ).

Table 1. Inpatient Demographic data and length of stay of the patients

\begin{tabular}{|c|c|c|c|c|c|c|}
\hline Gender & Mean Age & \multicolumn{2}{|c|}{ Inpatient } & Outpatient & Length of $^{1}$ Stay & $p_{\text {Value }}^{2}$ \\
\hline & & Service & Intensive care & & & \\
\hline Male & 38 & 4 & 2 & 106 & 4 & 0.379 \\
\hline Female & 34 & 7 & 0 & 222 & 4 & 0.379 \\
\hline Total & 36 & 11 & 2 & 328 & 4 & \\
\hline
\end{tabular}

${ }^{1}$ Average number of days spent in the hospital

${ }^{2}$ The result of comparing the gender and length of stay in hospital with the Kruskal Wallis Test 
Table 2. Distribution of COVID-19 Positive Healthcare Personnel

\begin{tabular}{|c|c|c|c|c|c|}
\hline & & Inpatient & Outpatient & Total & Percent $\%^{1}$ \\
\hline Job Groups & Doctor & 2 & 33 & 35 & 10.3 \\
\cline { 2 - 6 } & Non-doctor staff & 6 & 156 & 162 & 47.6 \\
\cline { 2 - 6 } & Worker & 4 & 139 & 143 & 42.1 \\
\hline \multirow{7}{*}{ Unit $^{2}$} & Emergency Service & 2 & 59 & 61 & 17.9 \\
\cline { 2 - 6 } & Clean Service & 3 & 40 & 43 & 12.6 \\
\cline { 2 - 6 } & COVID-19 Service & 4 & 36 & 40 & 11.8 \\
\cline { 2 - 6 } & Clean Intensive Care & 2 & 35 & 37 & 10.9 \\
\cline { 2 - 6 } & COVID-19 ICU & 0 & 33 & 33 & 9.7 \\
\cline { 2 - 6 } & General Areas & 0 & 31 & 31 & 9.1 \\
\cline { 2 - 6 } & Administrative units & 1 & 23 & 24 & 7.1 \\
\cline { 2 - 6 } & Outpatient Clinics & 0 & 24 & 24 & 7.1 \\
\cline { 2 - 6 } & Operating Room & 0 & 12 & 12 & 3.5 \\
\cline { 2 - 6 } & Support Units & 0 & 7 & 7 & 2.1 \\
\cline { 2 - 6 } & Hospital Pharmacy & 0 & 5 & 5 & 1.5 \\
\cline { 2 - 6 } & Laboratory & 0 & 5 & 5 & 1.5 \\
\cline { 2 - 6 } & Laundry & 0 & 4 & 4 & 1.2 \\
\cline { 2 - 6 } & Central & 0 & 4 & 3 & 1.2 \\
\cline { 2 - 6 } & Delivery Room & 0 & 4 & 3 & 0.9 \\
\cline { 2 - 6 } & Radiology & 0 & 3 & 3 & 0.9 \\
\cline { 2 - 6 } & Home Health Services & 0 & 3 & 3 & \\
\hline
\end{tabular}

${ }^{1}$ Percentage of allCOVID-19 RT-PCR positive staff

${ }^{2}$ Hospital unit where staff work

When the occupational groups of healthcare professionals were examined, it was found that COVID-19 RT-PCR positive non-physician healthcare workers number was $162(47.6 \%)$, the number of workers was $143(42.1 \%)$, the number of doctors was 35 (10.3\%).

No statistically significant difference was found between healthcare personnel's occupational groups and their hospitalisation status (Pearson Chi-Square, $\mathrm{p}=0.651$ ).

When the patients' conditions were examined according to their working units in the hospital, it was observed that the emergency service workers were most infected from COVID-19 with 61 cases $(17.9 \%)$ ). After that respectively, 43 people (12.6\%) who worked in clean wards, 40 people (11.8\%) in COVID-19 wards, 37 people $(10.9 \%)$ in clean intensive care units, and 33 people $(9,7 \%)$ in COVID-19 intensive care units accompanied the group. The number and rates of staff who were COVID-19 RT-PCR positive according to the work units are shown in Table 2.

When physician's workplaces were analysed, it was observed that the maximum rate of COVID-19 RT-PCR positive physicians was in COVID-19 services (16 people, $45.7 \%$ ) and emergency services (13 people, $37.1 \%$ ). On the other hand, the units where 162 non-physician healthcare professionals worked positively were the emergency service (32 people, 19.8\%), clean service (31 people, 19.1\%), clean intensive care units (27 people, 16.7\%), COVID-19 service (18 people, $11.1 \%)$ and COVID-19 intensive care units (18 people, $11.1 \%$ ).

The distribution of all other RT-PCR positive personnel according to their working areas were general areas (31 people, 23.5\%), emergency service (15 people, $11.4 \%$ ), polyclinic (15 people, $11.4 \%$ ), clean wards (11 people, 8.3\%), COVID-19 intensive care units (11 people, $8.3 \%$ ).

Thus, 134 (39.4\%) HCW were working in the emergency department, COVID-19 services, COVID-19 intensive care units; besides a total of $206(60.6 \%)$, $\mathrm{HCW}$ were working in non-COVID-19 areas.

\section{DISCUSSION}

In the COVID-19 pandemic, health workers were physically and psychologically challenged; furthermore, sometimes they had COVID-19 infection. Albert and Rozita stated that $12393 \mathrm{HCW}$ infected with SARS-CoV-2 in Germany by May 25, 2020, and 567 (4.6\%) of these health workers were hospitalised, 
$20(0.2 \%)$ of them died; moreover, $63.9 \%$ of infected HCW were nurses (9). Jameela et al. checked 16,912 health workers in 14 hospitals in Qatar between March 10, 2020 and June 26, 2020, and they noted that 1799 (10.6\%) tested positive for COVID-19, and $65.6 \%$ of them were male (10). It was recorded that $11.6 \%$ of these cases were hospitalised, and $0.6 \%$ required intensive care unit, while there were no deaths (10). In a retrospective study conducted in Wuhan, China, Jie Lu et al. observed that $64 \mathrm{HCW}$ infected with COVID-19, but none of them needed intensive care (11). Kasper and colleagues analysed 28,792 $\mathrm{HCW}$ between April 15, 2020 to April 23, 2020 in an observational cohort study conducted in Denmark and asseverated that 1163 (4.04\%) HCW tested positive for COVID-19 and $71 \%$ of them were women (7). Kramer et al. notified that $2.8 \%$ of $3669 \mathrm{HCW}$ in Germany infected with COVID-19 between April 15, 2020 and May 1, 2020, of which $61 \%$ were women (12). Nicola et al. also reported that $82(13.8 \%) \mathrm{HCW}$ were COVID-19 positive, of which $68.3 \%$ were women in a survey of 595 health workers; furthermore, most of them were young and nurses. According toour research's results, $340 \mathrm{HCW}$ in SEAH infected with COVID-19 between November 1, 2020 and November 30, 2020. The above studies and this study did not cover the whole pandemic period but were conducted over specific periods. However, $67.1 \%$ of the $\mathrm{HCW}$ infected in our study were women correlated with other research, except Jameela et al. The reason female employees contracted COVID-19 at such a prevailing rate may be that women frequently perform the nursing profession. In support of this, Albert and Rozita published that $63.9 \%$ of infected medical personnel, Nicola 70.1\%, Kasper 34.5\%, Liu and colleagues $67 \%$, and Stock et al. 33.2\% were nurses (7, $9,11,13,14)$. Contrary to these studies and our study, in Jameela et al.'s research, COVID-19 positivity was predominately found in male health workers (10). This may be because $75 \%$ of the Qatar population is made up of men (15). However, it is impossible to conclude this issue due to the limited data on the HCW's gender distribution in Qatar hospitals. Besides, in Jameela et al.'s study, midwives and nurses rates among the healthcare workers infected with COVID-19 are at the top with $33.2 \%$ (10).

Jameela et al. reported that only $5 \%$ of HCW infected with COVID-19 work in healthcare facilities where COVID-19 patients were cared for (10). Besides, in the early days of the pandemic, data from China indicated that healthcare workers infected with COVID-19 from healthcare facilities, while later research in German hospitals declared that HCW contaminated with COVID-19 might have acquired the disease from the community (16). Jie Lu et al. also ascertained that just
$18 \%$ of HCW infected with COVID-19 had a history of touch with COVID-19 cases or patients' samples (11). Albert and Rozita affirmed that $80 \%$ of the 224 HCW who were COVID-19 RTPCR positive until April 11, 2020 in Malaysia acquired the infection from the community (9). In our study, it was observed that $60.4 \%$ of the infected HCW were serving in clean areas, where there were no COVID-19 patients. Thus, the results of our study agreed with the conclusions of the above research. On the other hand; Kasper et al. reported that COVID-19 seroprevalence was significantly higher in those working in the COVID wards than other healthcare professionals (7).

Kramer et al., COVID-19 positivity was found more frequently in the emergency department, intensive care unit, and COVID wards than those working in other hospital's non-COVID areas (12). In our study, the high rate of positivity in healthcare professionals working in non-COVID areas supports the result of HCW acquired COVID-19 from the community. Also, Albert and Rozita are the fundamental reasons HCW in Malaysia infected with COVID-19; designated that insufficient PPE was used and there was no suspicion of COVID-19 in the patient (9). This study result can be interpreted that, HCW working in the non-COVID areas are not more concerned about wearing PPE.

\section{CONCLUSION}

The COVID-19 outbreak has negatively influenced healthcare workers as well as the whole society. HCW are at risk of COVID-19 infection in addition to the enhanced workload. Especially all HCW who are in close contact with any patient should be extra careful. Throughout the COVID-19 pandemic, healthcare professionals working in non-COVID areas should also provide healthcare service cautiously. As well as healthcare professionals are circumspect about infection transmission in their social lives outside of the hospital, it may help decrease the number of healthcare workers infected with COVID-19.

\section{Abbreviations}

HCW - healthcare workers

PPE - personal protective equipment

RT-PCR - Reverse Transcription Polymerase Chain Reaction

SEAH - Sakarya University Training and Research Hospital

\section{Acknowledgment}

None. 
Conflict of Interests: The authors declare that there are no conflicts of interest related to this article.

Funding: None

\section{Licensing}

This work is licensed under a Creative Commons Attribution 4.0 International (CC BY 4.0) License.

\title{
Sažetak
}

\section{DEMOGRAFSKE KARAKTERISTIKE POZITIVNIH ZDRAVSTVENIH RADNIKA NA KOVID-19 I POREĐENJE SA LITERATUROM}

\author{
Durmus Ensar, Guneysu Fatih \\ Emergency Department, Sakarya University Training and Research Hospital, Sakarya, Turkey
}

CILJ: Cilj je da se ispitaju status i demografske karakteristike KOVID-19 RT-PCR pozitivnog osoblja koje radi u bolnici tokom perioda pandemije.

Metode i materijal: Ovo je retrospektivno, deskriptivno istraživanje. Sve osoblje bolnice koje radi u bolnici za obuku i istraživanje Sakaria i ima pozitivan test na KOVID-19 RT-PCR u periodu od 01.11. je uključeno u istraživanje.

Rezultati: Tokom perioda ispitivanja, broj bolničkog osoblja koje je imalo pozitivan test na KOVID-19 RT-PCR bio je 340 ljudi. Od osoblja, $228(67,1 \%)$ su bile žene, prosečna starost svih zdravstvenih radnika bila je $32,7 \pm 8,3$ ) godina. Broj zdravstvenih radnika koji nisu lekari bio je 162

\section{REFERENCES}

1. WHO announces COVID-19 outbreak a pandemic [Internet]. World Health Organization; 2020 [cited 2020 Apr 11]. Available from: http://www.euro.who.int/en/health-topics/ health-emergencies/coronavirus-covid-19/news/news/2020/3/ who-announces-covid-19-outbreak-a-pandemic.

2. Vizheh M, Qorbani M, Arzaghi SM, Muhidin S, Javanmard Z, Esmaeili M. The mental health of healthcare workers in the COVID-19 pandemic: A systematic review. J Diabetes Metab Disord. 2020; 19(2):1-12. doi: 10.1007/s40200-02000643-9.

3. Lucchini A, Iozzo P, Bambi S. Nursing workload in the COVID-19 era. Intensive Crit Care Nurs. 2020; 61:102929. doi: 10.1016/j.iccn.2020.102929.

4. Shaukat N, Ali DM, Razzak J. Physical and mental health impacts of COVID-19 on healthcare workers: a scoping review. Int J Emerg Med. 2020; 13(1): 40. doi: 10.1186/s12245020-00299-5.

5. Pan American Health Organization (PAHO)/World Health Organization (WHO) 2020. COVID-19 has Infected Some 570.000 Health Workers and Killed 2,500 in the Americas. [cited 2020 Sep 27]. Available from: https://www.paho.org/ en/news/2-9-2020-covid-19-has-infected-some-570000-healthworkers-and-killed-2500-americas-paho.

6. Erdem H, Lucey DR. Healthcare worker infections and deaths due to COVID-19: A survey from 37 nations and a call for WHO to post-national data on their website. Int J Infect Dis. 2021; 102: 239-41. doi: 10.1016/j.ijid.2020.10.064.
$(47,6 \%)$, radnika $143(42,1 \%)$, a lekara $35(10,3 \%)$. Među svim bolničkim osobljem, test KOVID-19 RTPCR bio je pozitivan kod radnika hitne pomoći, sa maksimalno 61 osobom (17,9\%). Zatim 43 (12,6\%) ljudi koji rade u ne-KOVID odeljenjima za čišćenje.

Zaključci: Bilo bi korisno da osoblje koje radi u bolnici tokom pandemije obrati pažnju da tokom svog rada primenjuje ličnu zaštitnu opremu, bez obzira na to da li pacijent sa KOVID-19 to isto čini ili ne. Istovremeno, zdravstveni radnici trebaju bit oprezni u pogledu prenošenja KOVID-19 u svom društvenom životu van bolnice.

Ključne reči: KOVID-19, zdravstveni radnik, Hitna služba.

7. Iversen $\mathrm{K}$, Bundgaard $\mathrm{H}$, Hasselbalch RB, Kristensen JH, Nielsen PB, Pries-Heje M, et al. Risk of COVID-19 in health-care workers in Denmark: an observational cohort study. Lancet Infect Dis. 2020; 20(12): 1401-8. doi: 10.1016/S14733099(20)30589-2.

8. George D, Mallery P. IBM SPSS statistics 25 step by step: a simple guide and reference. Fifteenth edition. New York ; London: Routledge, Taylor \& Francis Group; 2019. 404 p.

9. Nienhaus A, Hod R. COVID-19 among Health Workers in Germany and Malaysia. Int J Environ Res Public Health. 2020; 17(13): 4881. doi: 10.3390/ijerph17134881.

10. Alajmi J, Jeremijenko AM, Abraham JC, Alishaq M, Concepcion EG, Butt AA, et al. COVID-19 infection among healthcare workers in a national healthcare system: The Qatar experience. Int J Infect Dis. 2020; 100: 386-9. doi: 10.1016/j. ijid.2020.09.027.

11. Liu J, Ouyang L, Guo P, Wu H, Fu P, Chen Y, et al. Epidemiological, clinical characteristics and outcome of medical staff infected with COVID-19 in Wuhan, China: A Retrospective Case Series Analysis [Internet]. Infectious Diseases (except HIV/AIDS); 2020 Mar [cited 2020 Dec 31]. Available from: http://medrxiv.org/lookup/doi/10.1101/2020.03.09.20033118.

12. Kramer V, Papazova I, Thoma A, Kunz M, Falkai P, Schneider-Axmann T, et al. Subjective burden and perspectives of German healthcare workers during the COVID-19 pandemic. Eur Arch Psychiatry Clin Neurosci. 2021; 271(2): 271-281. doi: 10.1007/s00406-020-01183-2.

13. Magnavita N, Tripepi G, Di Prinzio RR. Symptoms in health care workers during the COVID-19 epidemic. A 
cross-sectional survey. Int J Environ Res Public Health. 2020; 17(14): 5218. doi: 10.3390/ijerph17145218.

14. Stock AD, Bader ER, Cezayirli P, Inocencio J, Chalmers SA, Yassari R, et al. COVID-19 infection among healthcare workers: serological findings supporting routine testing. Front Med. 2020; 7: 471. doi: 10.3389/fmed.2020.00471.

15. Woman and Man- A Statistical Portrait 2018 [Internet]. Doha: Planning and Statistics Authority; 2018 Dec [cited

\section{Correspondence to/Autor za korespondenciju}

Ensar Durmus, MD

Sakarya Training and Research Hospital

Department of Emergency Medicine

Sakarya, TURKEY

Phone: +90505866 5782

e-mail: muhalefet@hotmail.com
2020 Jan 6] p. 22. Available from: https://www.psa.gov.qa/en/ statistics/Statistical\%20Releases/Social/GenrealSocialStatistics/MenWomenProfile/2018/Woman_Man_2018_EN.pdf.

16. Bielicki JA, Duval X, Gobat N, Goossens H, Koopmans $\mathrm{M}$, Tacconelli $\mathrm{E}$, et al. Monitoring approaches for health-care workers during the COVID-19 pandemic. Lancet Infect Dis. 2020; 20(10): e261-7. doi: 10.1016/S14733099(20)30458-8. 